\title{
Regulation of leptin production: a dominant role for the sympathetic nervous system?
}

\author{
Paul Trayhurn*, Jacqueline S. Duncan, Nigel Hoggard and D. Vernon Rayner \\ Molecular Physiology Group, Division of Biomedical Science, Rowett Research Institute, \\ Bucksburn, Aberdeen AB21 9SB, UK
}

Unravelling the diverse hormonal and neuroendocrine systems which regulate energy balance and body fat has been a long-standing challenge in biology, with obesity as an increasingly important public health focus. A major development in energy balance regulation has come with the discovery in 1994 of a 'new' hormone, leptin, the protein product of the $o b$ (obese) gene (Zhang et al. 1994). The initial concept was that leptin was synthesized in white adipose tissue, being secreted into the circulation as a signal of the extent of the fat stores, in accordance with the lipostatic model of the regulation of energy balance (Kennedy, 1953). The newlyidentified hormone was first viewed as influencing energy balance by acting centrally to inhibit food intake, i.e. leptin was considered to be a satiety factor (Zhang et al. 1994).

The original view of the leptin system (where the hormone is produced, the target tissues, and the physiological functions that are regulated), however, has evolved considerably over the past 3 years. In the present article we describe the sites of leptin synthesis and discuss the regulation of the production of the hormone. We consider, in particular, whether physiologically the sympathetic nervous system (SNS) plays a dominant role in controlling the production of leptin in white adipose tissue.

\section{Where is leptin produced?}

White adipose tissue is the main site of leptin production, but it is now evident that the hormone is also produced in other tissues. Initial studies on brown adipose tissue were equivocal, with some authors observing little or no evidence for expression of the $o b$ gene by Northern blotting (Maffei et al. 1995a; Trayhurn et al. 1995b), while others reported high levels of $o b$ mRNA in the organ (Moinat et al. 1995). In our laboratory we have not generally detected $o b$ mRNA on Northern blots of total RNA from brown fat, but $o b$ gene expression is evident when the more sensitive technique of reverse transcription-polymerase chain reaction is employed. Definitive evidence for brown adipose tissue as a site of leptin production has now come, however, from several different directions: (1) studies on brown adipocytes in primary culture (Deng et al. 1997); (2) studies on brown adipose tissue of newborn rats (Dessolin et al. 1997b) and Djungarian hamsters (Klingenspor et al. 1996); (3) an immunohistochemical study on $d b / d b$ mice (Cinti et al. 1997). A central issue is the physiological role of leptin produced by brown fat, one possibility being that it simply adds to the pool of circulating hormone as a reflection of the total combined amount of adipose tissue (white and brown); its contribution would, however, be small relative to that of white fat (Giacobino, 1996). The significance of brown fat as a site of leptin synthesis is made more problematic by the fact that the tissue is neither present in all mammals nor is it necessarily evident throughout life in those species in which it does occur (see Trayhurn, 1995).

An important new dimension to leptin biology has come with the recognition that the placenta expresses the $o b$ gene and is a site of production of the hormone; this has now been demonstrated in mice, rats and man (Hassink et al. 1997; Hoggard et al. 1997; Masuzaki et al. 1997). Placental synthesis is particularly intriguing, and suggests that leptin may either be a novel growth factor or act as a signal of energy status between the mother and the fetus. The placenta also expresses the leptin receptor gene, implying that the organ is a target for the action of leptin as well as being a source of the hormone (Hoggard et al. 1997). In situ hybridization and immunohistochemical studies on pregnant mice have demonstrated leptin synthesis in several regions of the fetus, including the heart, bone and cartilage, and cells of the hair follicle, observations which are discussed in more detail in the accompanying article (Hoggard et al. 1998). This diverse picture of where leptin is produced indicates that the functions of the hormone extend considerably beyond the basic lipostatic model originally envisaged.

White adipose tissue is a heterogeneous organ located in a number of distinct sites. Although each of the major white fat depots appears to express the $a b$ gene, there are considerable differences between sites in the relative level of $o b$ mRNA (Maffei et al. 1995a; Trayhurn et al. 1995b). In adult rodents, $a b$ mRNA level is much higher in the gonadal and perirenal sites than in subcutaneous tissue (Trayhurn et al. $1995 b$ ). In contrast, in sucking rats during the first 1-2 weeks after birth the subcutaneous fat is the main site of $o b$ gene expression (Rayner et al. 1997). If relative levels of $a b$ mRNA can be taken to reflect the pattern of leptin production, it would seem that there are major differences between depots in the extent to which they contribute to the total circulating pool of the hormone. Furthermore, the rodent data also imply that there are developmental shifts in the relative 
importance of different adipose tissue sites to leptin production. In sucking animals the subcutaneous fat is of greatest importance, whilst in the mature animal the internal depots are more significant.

There are also distinct species variations, in that in adult human subjects the subcutaneous adipose tissue has much higher levels of $o b$ mRNA, and is likely, therefore, to be more important in leptin production than the omental tissue (Hube et al. 1996; Montague et al. 1997). The production of a hormone at varying levels from a number of different sites raises questions in terms of co-ordination, particularly given the evidence that leptin is secreted in a pulsatile manner (Sinha et al. 1996; Licinio et al. 1997).

\section{Regulation of leptin production}

The level of $o b$ mRNA in white adipose tissue and the circulating leptin concentration are increased markedly in obesity, as shown in both human studies and in studies on several types of obese animal (Frederich et al. 1995; Funahashi et al. 1995; Lönnqvist et al. 1995a; Maffei et al. 1995b; Ogawa et al. 1995; Trayhurn et al. 1995b; Considine et al. 1996; Hardie et al. 1996b; Ostlund et al. 1996). Indeed, in human subjects there is a high correlation between BMI and circulating leptin (Considine et al. 1996; Ostlund et al. 1996). Thus, the greater the amount of adipose tissue, the higher the level of the hormone. However, acute (and chronic?) regulation of leptin synthesis is superimposed on the endogenous production associated with the extent of the adipose tissue mass.

Both in vivo and in vitro studies have been undertaken to examine the factors which influence expression of the $o b$ gene and the production of leptin. In in vitro studies direct rather than indirect effects of a regulatory factor can, of course, be defined. With white adipose tissue three different in vitro systems are available: (1) incubation of isolated mature adipocytes (Murakami et al. 1995; Gettys et al. 1996; Hardie et al. 1996a; Rentsch \& Chiesi, 1996; Slieker et al. 1996); (2) adipocyte clonal cell lines, e.g. 3T3L1 cells (MacDougald et al. 1995; LeRoy et al. 1996; Dessolin et al. $1997 a$ ); (3) adipocytes differentiated in primary culture from fibroblastic pre-adipocytes (Wabitsch et al. 1996; Mitchell et al. 1997). Isolated mature adipocytes will secrete leptin during incubation for a period of $24-48 \mathrm{~h}$ (Hardie et al. $1996 a$ ), while white adipocytes differentiated in primary culture (both human and rat) have been shown to secrete the hormone over a period of about 2 weeks following differentiation (Wabitsch et al. 1996; Mitchell et al. 1997).

Adipocyte cell culture studies and studies in vivo have shown that both insulin and glucocorticoids stimulate $o b$ gene expression (Becker et al. 1995; De Vos et al. 1995; Saladin et al. 1995; Leroy et al. 1996; Wabitsch et al. 1996). Testosterone (or dihydrotestosterone), on the other hand, inhibits leptin production in primary cell culture (Wabitsch et al. 1997). Since there is a negative relationship between serum testosterone and BMI in men (Elbers et al. 1997; Wabitsch et al. 1997), this is consistent with the concept that a suppressive effect of androgens is the primary reason for the lower circulating levels of leptin in males compared with females, even when adjustments for body fatness are made.
Some modest inhibition of leptin production by growth hormone has been observed in human adipocytes in primary culture (Wabitsch et al. 1997), although not with mature rat adipocytes (Hardie et al. 1996a). Hypophysectomy results in a fall in $o b$ mRNA levels, but this is not reversed by the administration of growth hormone (Boni-Schnetzler et al. 1996). Other agents which influence expression of the $o b$ gene in white fat include thiazolidinediones (drugs that activate peroxisome proliferator-activated receptor $\gamma$ ), which are inhibitory (De Vos et al. 1996; Kallen \& Lazar, 1996). There is conflicting evidence as to the effects of thyroid hormones on leptin production, with some suggesting that triiodothyronine is inhibitory (Fain et al. 1997), while others suggest that it is stimulatory (Yoshida et al. 1997). Our own work using adipocytes differentiated in primary culture has found, however, no effect of triiodothyronine on leptin production, but thyroxine was markedly inhibitory (SE Mitchell and $P$ Trayhurn, unpublished results). Circulating leptin levels in human subjects appear not to be under the control of thyroid hormones, at least in the short-term (Mantzoros et al. 1997).

Physiological influences on leptin production include fasting and acute exposure to cold, both resulting in a reduction in $a b$ gene expression and a fall in circulating leptin (Becker et al. 1995; MacDougald et al. 1995; Trayhurn et al. 1995a,b; Hardie et al. 1996b). Refeeding after fasting leads to a rapid restoration of gene expression and plasma leptin (Becker et al. 1995; Trayhurn et al. 1995b; Hardie et al. $1996 b$ ). Thus, leptin production is subject to nutritional regulation in a manner consistent with a central role for the hormone in the control of energy balance. Cold exposure induces a substantive rise in energy expenditure, through shivering and non-shivering thermogenesis, and this is fuelled by a major increase in substrate flux. Since food intake gradually rises during prolonged exposure to cold, inhibition of the synthesis of a hormone which acts as a satiety factor is an appropriate response. Interestingly, transfer of animals from a cold to a warm environment quickly leads to a restoration of $o b \mathrm{mRNA}$ levels in white adipose tissue, and to the normalization of circulating leptin (Trayhurn et al. 1995a; Hardie et al. 1996b).

In a study on fasted golden hamsters, fever induced by lipopolysaccharide was found to result in a stimulation of $o b$ gene expression, an effect which was mimicked by administration of the cytokines tumour necrosis factor- $\alpha$ or interleukin-1 (Grunfeld et al. 1996).

\section{$\beta$-Agonists and the $\beta 3$-adrenoceptor}

The SNS plays a pivotal role in the regulation of the increased energy expenditure associated with the adaptive response to cold, particularly in relation to the stimulation of thermogenesis in brown adipose tissue (see Landsberg \& Young, 1984). Administration of noradrenaline or the nonspecific $\beta$-adrenoceptor agonist, isoprenaline, inhibits $o b$ gene expression in white fat (Trayhurn et al. 1995a), and we have recently observed that acute treatment with noradrenaline and isoprenaline leads to a reduction in circulating leptin levels (A Mostyn, DV Rayner and P Trayhurn, unpublished results). These results suggest that the cold-induced fall in leptin production may be mediated by the SNS. Additionally, 
isoprenaline has been shown to induce an acute suppression of plasma leptin in human subjects (Pinkney et al. 1998).

The general effects of catecholamines and $\beta$-agonists obtained in whole-animal studies are paralled in studies on mature adipocytes, on adipocytes from clonal cell lines and with differentiated adipocytes in primary culture (Gettys et al. 1996; Hardie et al. 1996a; Dessolin et al. 1997a; Mitchell et al. 1997). This indicates that there is a direct interaction between catecholamines and white adipose tissue in the control of leptin production. The inhibition appears to occur primarily through $\beta 3$-adrenoceptors, since both in vivo and in vitro studies have shown that selective $\beta 3$-agonists (e.g. BRL 35153A, CL316243, Ro 16-8714) have a powerful suppressive effect on $o b$ gene expression with a rapid reduction in circulating leptin (Moinat et al. 1995; Gettys et al. 1996; Mantzoros et al. 1996; Slieker et al. 1996; Trayhurn et al. 1996; Dessolin et al. 1997a).

These results have led to the proposition that the SNS is involved in a negative feedback loop to white adipose tissue, regulating leptin production by inhibiting $o b$ gene transcription through $\beta 3$-adrenoceptors (Trayhurn et al. 1995a,1996; Giacobino, 1996). The regulatory effects of the SNS are mediated by the CAMP second messenger system since dibutyryl cAMP, bromo-cAMP and forskolin strongly suppress leptin production in adipocyte cell culture systems (Slieker et al. 1996; SE Mitchell and $\mathrm{P}$ Trayhurn, unpublished results). In this regard, it is pertinent to note that a cAMP response element has been reported in the promoter region of the human ob gene (Gong et al. 1995).

The importance of the $\beta 3$-adrenoceptor in modulating $o b$ gene expression is also indicated by the results of studies on the effects of $\beta 3$-agonists on $o b \mathrm{mRNA}$ levels in obese $(o b / o b)$ mice. In contrast to lean animals, there is only a limited fall in $o b$ mRNA in white fat of $o b / o b$ mice following treatment with BRL 35153A (Trayhurn et al. 1996), the obese mutants having a greatly reduced expression of B3-adrenoceptors in their adipose tissue (Collins et al. 1994), with the stimulation of adenyl cyclase $(E C 4.6 .1 .1)$ by $\beta 3$-agonists being blunted (Bégin-Heick, 1996). Similarly, obese $\mathrm{fa} / \mathrm{fa}$ rats also show down-regulation of $\beta 3$-adrenoceptor expression in white fat (Muzzin et al. 1991), and unlike their lean siblings there is no reduction in circulating leptin levels on cold exposure (Hardie et al. 1996 b).

The significance of $\beta 3$-adrenoceptors in the control of leptin production in human subjects is uncertain, although there is evidence that the receptor may play an important role in the control of lipolysis in human omental and subcutaneous adipose tissue (Enocksson et al. 1995; Lönnqvist et al. $1995 b)$.

\section{A key regulatory role for the sympathetic nervous system?}

\section{Sympathetic system and lipolysis}

In the preceding section the major factors so far shown to regulate the production of leptin have been described. An important question is whether physiologically any one particular factor plays a predominant role, and whether a specific agent that modulates leptin production in vitro in isolation from other factors may have significance in vivo. There is a parallel with the regulation of lipolysis in white fat, which in vitro studies have indicated may involve an array of hormones, including glucagon, catecholamines, growth hormone and adrenocorticotrophin (see Hales et al. 1978). However, it has long been considered probable that in vivo the SNS is the key regulator of lipolysis. Evidence in support of this view includes the following observations: (1) denervation leads to an increase in adipose tissue mass; (2) electrical stimulation of the nerves to white adipose tissue results in fatty acid release; (3) pharmacological abolition of sympathetic activity inhibits the mobilization of lipids (Hales et al. 1978).

One of the long-standing issues in assessing whether the key functions of white adipose tissue may be regulated by the SNS is the extent to which the tissue is innervated. There is, however, general agreement that white fat does receive a sympathetic innervation, which, although primarily linked to the vasculature, also involves the adipocytes themselves (Fredholm, 1985; Slavin, 1985; Youngström \& Bartness, 1995). Apart from any direct effects of the SNS within white fat, there is also the possibility of an indirect interaction via the sympathetic innervation of the adrenals, with the release of adrenaline into the circulation.

Until recently, direct changes in sympathetic activity in white adipose tissue in response to physiological stimuli which result in increased lipolysis had not been demonstrated, and this is pivotal to the concept that the SNS is the principal regulator of lipolysis. However, a study measuring noradrenaline turnover has now demonstrated that sympathetic activity in white adipose tissue is increased on cold exposure (Garofalo et al. 1996). This change parallels the well-documented increase in sympathetic stimulation to brown fat and the heart in the cold (see Landsberg \& Young, 1984). The same group has gone on to demonstrate that fasting, on the other hand, selectively increases sympathetic activity in white fat (Migliorini et al. 1997), in contrast to brown adipose tissue and the heart where there is a marked decrease (Landsberg \& Young, 1984).

\section{Sympathetic activity and leptin in fasting}

From these observations it is pertinent to ask whether the reduction in circulating leptin during fasting is primarily the result of an inhibitory effect on $o b$ gene transcription resulting from increased SNS activity to white fat (Giacobino, 1996), and not to alternative explanations such as falling insulin levels. Some direct evidence in support of such a notion comes from a recent study in which we have examined the effects of administering the $\beta$-adrenoceptor antagonist, propranolol, to mice. Treatment with propranolol led to a significant attenuation in the fasting-induced reduction in circulating leptin (Fig. 1). There was, however, no effect of propranolol on the leptin level in fed mice. Although the effects of propranolol are not dramatic, it is recognized that this compound is not a proficient antagonist of $\beta 3$-adrenoceptors, the key $\beta$-receptor subtype through which the SNS appears to regulate $o b$ gene transcription.

In contrast to lean animals, fasting has no effect on $o b$ mRNA levels in white adipose tissue of $o b / a b$ mice (Trayhurn et al. 1995b) and nor is there any acute effect of food deprivation on the circulating level of leptin in $\mathrm{fa} / \mathrm{fa}$ rats 
(Hardie et al. 1996b). Given the defects in $\beta 3$-adrenoceptor expression in both types of obese mutant referred to earlier, a lack of response to fasting would be consistent with a central role for the SNS in the fasting-induced fall in leptin production.

\section{Effects of blockade of noradrenaline synthesis on circulating leptin}

An approach that we have utilized in attempting to assess the physiological significance of the SNS in the regulation of leptin production is to examine the effects of inhibiting the synthesis of noradrenaline. The rate-limiting enzyme in noradrenaline synthesis is tyrosine hydroxylase $(E C$ 1.14.16.2), and this can be strongly inhibited by $\alpha$-methyl-p-tyrosine. Indeed, one of the standard methods for determining SNS activity is to inhibit the synthesis of noradrenaline with $\alpha$-methyl- $p$-tyrosine and measure the subsequent rate of fall in the concentration of catecholamine in the tissue(s) of interest. Not only has $\alpha$-methyl- $p$-tyrosine been employed as a tool for measuring sympathetic activity, but it has also been used clinically to treat patients with phaeochromocytoma (characterized by a hypersecretion of catecholamines).

Administration of $\alpha$-methyl- $p$-tyrosine to mice at the levels employed in, and with a protocol similar to, studies on noradrenaline turnover induces a rapid increase in the

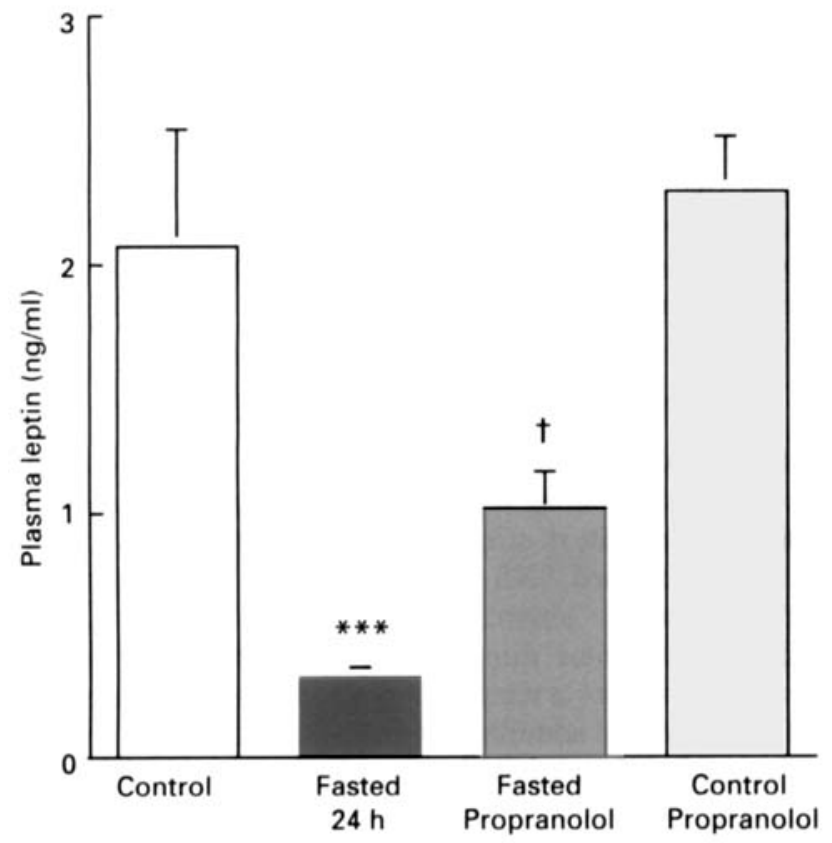

Fig. 1. Effects of the $\beta$-adrenoceptor antagonist, propranolol, on the circulating leptin level in fed and fasted mice. Aston strain mice were either fasted for $24 \mathrm{~h}$ or allowed to feed ad libitum. Animals in each group were injected intraperitoneally with $20 \mathrm{mg}$ (-)propranolol $/ \mathrm{kg}$ or saline $(9 \mathrm{~g} \mathrm{NaCl} / \mathrm{l})$ at 0,16 and $20 \mathrm{~h}$ after the removal of food. Plasma leptin was measured by ELISA using a murine recombinant leptin standard (Hardie et al. 1996b). Results are given as means with their standard errors represented by vertical bars for six to eight mice in each group. Mean value was significantly different from that for the fed control group: ${ }^{* \star \star} P<0.001$. Mean value was significantly different from that for fasted group (Student's $t$ test): ${ }^{\dagger} P<0.05$. circulating level of leptin (Fig. 2). In subsequent studies, we have found that leptin levels are elevated by up to 8 -fold within $6-10 \mathrm{~h}$ after the injection of $\alpha$-methyl-ptyrosine. Thus, blockade of noradrenaline production leads to marked hyperleptinaemia. In principle, hyperleptinaemia could result from either increased production of the hormone or decreased removal, or a combination of the two. That there is an elevation in synthesis is indicated by examination of $o b$ mRNA in white adipose tissue; $10 \mathrm{~h}$ after treating mice with $\alpha$-methyl- $p$-tyrosine the level of $o b$ mRNA in the epididymal white fat was increased by up to 5 -fold (E Simon, JS Duncan, DV Rayner and P Trayhurn, unpublished results).

Further experiments have shown that if a selective $\beta 3$-adrenoceptor agonist is administered, then the rise in leptin levels induced by treatment with $\alpha$-methyl-p-tyrosine is attenuated (E Simon, DV Rayner and P Trayhurn, unpublished results). This indicates that direct stimulation of $\beta 3$-adrenoceptors circumvents the effects of the blockade of noradrenaline synthesis on leptin production, as would be predicted.

Overall, these findings are consistent with the concept that the SNS is playing a key role in the regulation of leptin production through modulating transcription of the $o b$ gene. Additional approaches to blocking SNS activity are required, however, to substantiate the hypothesis presented here. Irrespective of whether $\alpha$-methyl-p-tyrosine is acting

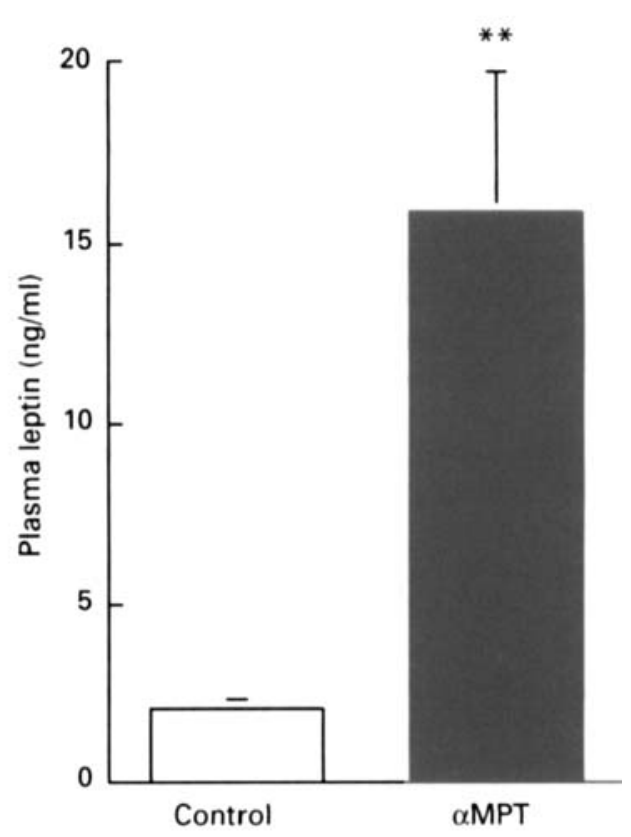

Fig. 2. Effect of tyrosine hydroxylase (EC 1.14.16.2) inhibitor $\alpha$-methyl- $p$-tyrosine ( $\alpha \mathrm{MPT}$ ) on circulating leptin levels in mice. Aston strain mice were injected with either $\alpha$ MPT (methyl ester; $300 \mu \mathrm{g} / \mathrm{kg}$ body weight) or saline $(9 \mathrm{~g} \mathrm{NaCl} / \mathrm{l})$ at 0,8 and $13 \mathrm{~h}$ and blood taken at $18 \mathrm{~h}$ after the first injection. Plasma leptin was measured by ELISA using a murine recombinant leptin standard (Hardie et al. 1996b). Results are given as means with their standard errors represented by vertical bars for eight mice in each group. Mean value was significantly different from that for the control group (Student's $t$ test): ${ }^{*} P<0.01$. 


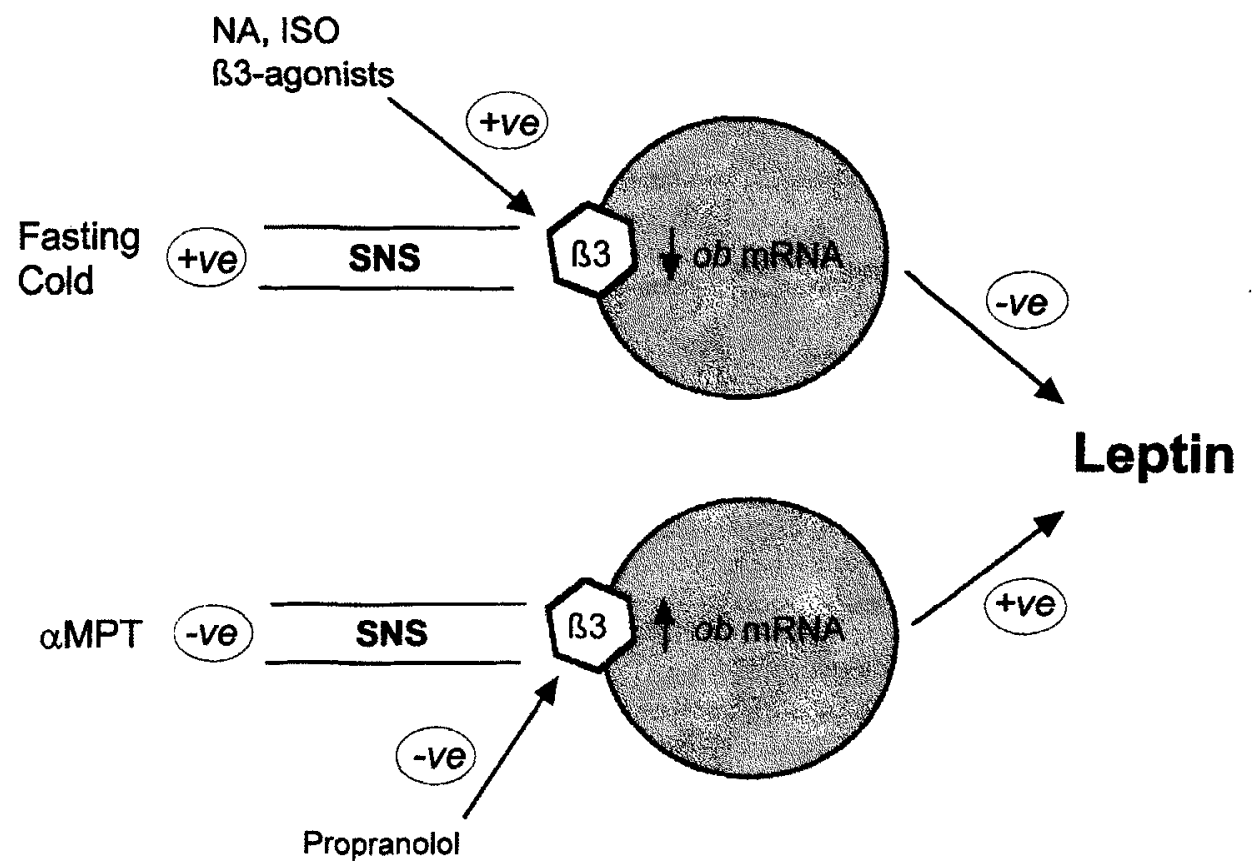

Fig. 3. Schematic view of the regulation of leptin production in white adipose tissue by the sympathetic nervous system (SNS). $\alpha$ MPT, $\alpha$-methyl-p-tyrosine; $\beta 3, \beta 3$-adrenoceptor; ISO, isoprenaline; NA, noradrenaline; -ve, negative effect; +ve, positive effect.

exclusively through the inhibition of tyrosine hydroxylase, there are certain implications of the results obtained with this. First, $\alpha$-methyl- $p$-tyrosine provides a pharmacological tool for the up-regulation of circulating leptin levels. Second, since there is evidence that leptin stimulates sympathetic activity to a number of tissues (Collins et al. 1996; Haynes et al. 1997), it is apparent that using $\alpha$-methyl-p-tyrosine as a tool to measure SNS activity leads to a change in the activity of that which is being measured.

\section{Coda}

A number of factors which influence the expression of the $o b$ gene and the production of leptin have been identified, and these include hormones such as insulin, glucocorticoids and testosterone. It is proposed that physiologically the SNS plays a dominant role, operating primarily through the $\beta 3$-adrenoceptor subtype (Fig. 3). Certainly the effects of catecholamines and $\beta$-agonists, both non-selective (isoprenaline) and $\beta 3$-adrenoceptor-selective, on leptin production are rather more pronounced than with other recognized regulatory factors. There is a clear analogy between the problem of identifying the critical physiological regulators of leptin production and the central factors involved in the control of lipolysis.

Our knowledge of the regulation of the expression of the $o b$ gene and the production of leptin relates primarily to white adipose tissue. It cannot be assumed, however, that the same factors are involved in regulating the expression of the $o b$ gene in other tissues. Nevertheless, $\beta 3$-adrenoceptor agonists appear to inhibit expression in brown adipose tissue, as in white fat (Moinat et al. 1995; Deng et al. 1997). That the regulatory systems differ in the placenta is indicated by the presence of a placental-specific enhancer (Bi et al. 1997), and by the augmentation of leptin secretion by the placental choriocarcinoma BeWo cell line in the presence of forskolin (Masuzaki et al. 1997; N Hoggard, unpublished results); in white adipocytes forskolin strongly inhibits leptin production.

\section{Acknowledgements}

We are grateful to the Scottish Office Agriculture, Environment and Fisheries Department for financial support.

\section{References}

Becker DJ, Ongemba LN, Brichard V, Henquin J-C \& Brichard SM (1995) Diet- and diabetes-induced changes of ob gene expression in rat adipose tissue. FEBS Letters 371, 324-328.

Bégin-Heick N (1996) $\beta$-Adrenergic receptors and G-proteins in the ob/ob mouse. International Journal of Obesity 20, Suppl. 3, S32-S35.

Bi S, Gavrilova O, Gong DW, Mason MM \& Reitman M (1997) Identification of a placental enhancer for the human leptin gene. Journal of Biological Chemistry 272, 30583-30588.

Boni-Schnetzler M, Gosteli-Peter MA, Moritz W, Froesch ER \& Zapf $\mathbf{J}$ (1996) Reduced ob mRNA in hypophysectomised rats is not restored by growth hormone (GH), but further suppressed by exogenously administered insulin-like growth factor (IGF) I. Biochemical and Biophysical Research Communications 225, 296-301.

Cinti S, Frederich RC, Zingaretti MC, De Matteis R, Flier JS \& Lowell BB (1997) Immunohistochemical localization of leptin and uncoupling protein in white and brown adipose tissue. Endocrinology 138, 797-804.

Collins S, Daniel KW, Rohlfs EM, Ramkumar V, Taylor IL \& Gettys TW (1994) Impaired expression and functional-activity of the $\beta 3$-adrenergic and $\beta 1$-adrenergic receptors in adipose tissue of congenitally obese (C57B1/6J ob/ob) mice. Molecular Endocrinology 8, 518-527. 
Collins S, Kuhn CM, Petro AE, Swick AG, Chrunyk BA \& Surwit RS (1996) Role of leptin in fat regulation. Nature 380, 677.

Considine RV, Sinha MK, Heiman ML, Kriauciunas A, Stephens TW, Nyce MR, Ohannesian JP, Marco CC, McKee LJ, Bauer TL \& Caro JF (1996) Serum immunoreactive-leptin concentrations in normal-weight and obese humans. New England Journal of Medicine 334, 292-295.

Deng CJ, Moinat M, Curtis L, Nadakal A, Preitner F, Boss O, Assimacopoulos-Jeannet F, Seydoux J \& Giacobino JP (1997) Effects of $\beta$-adrenoceptor subtype stimulation on obese gene mRNA and on leptin secretion in mouse brown adipocytes differentiated in culture. Endocrinology 138, 548-552.

Dessolin S, Dani C \& Ailhaud G (1997a) Regulation of obese gene expression and leptin secretion in adipose cells by insulin and $\beta$-adrenoceptor agonists. In Leptin - the Voice of Adipose Tissue, pp. 91-101 [WF Blum, W Kiess and W Rascher, editors]. Heidelberg, Germany: J. A. Barth Verlag.

Dessolin S, Schalling M, Champigny O, Lonnqvist F, Ailhaud G, Dani C \& Ricquier D (1997b) Leptin gene is expressed in rat brown adipose tissue at birth. FASEB Journal 11, 382-387.

De Vos P, Lefebvre AM, Miller SG, Guerre-Millo M, Wong K, Saladin R, Hamann LG, Staels B, Briggs MR \& Auwerx J (1996) Thiazolidinediones repress $o b$ gene expression in rodents via activation of peroxisome proliferator-activated receptor gamma. Journal of Clinical Investigation 98, 1004-1009.

De Vos P, Saladin R, Auwerx J \& Staels B (1995) Induction of $o b$ gene expression by corticosteroids is accompanied by body weight loss and reduced food intake. Journal of Biological Chemistry 270, 15958-15961.

Elbers JMH, Asscheman H, Seidell JC, Frölich M, Meinders AE \& Gooren LJG (1997) The effect of sex steroid hormones on serum leptin levels. In Leptin - the Voice of Adipose Tissue, pp. 246-254 [WF Blum, W Kiess and W Rascher, editors]. Heidelberg, Germany: J. A. Barth Verlag.

Enocksson S, Shimizu M, Lönnqvist F, Nordenström J \& Arner P (1995) Demonstration of an in vivo functional $\beta 3$-adrenoceptor in man. Journal of Clinical Investigation 95, 2239-2245.

Fain JN, Coronel EC, Beauchamp MJ \& Bahouth SW (1997) Expression of leptin and $\beta 2$-adrenergic receptors in rat adipose tissue in altered thyroid states. Biochemical Journal $\mathbf{3 2 2}$, 145-150.

Frederich RC, Löllmann B, Hamann A, Napolitano-Rosen A, Kahn BB, Lowell BB \& Flier JS (1995) Expression of ob mRNA and its encoded protein in rodents: impact of nutrition and obesity. Journal of Clinical Investigation 96, 1658-1663.

Fredholm BB (1985) Nervous control of circulation and metabolism in white adipose tissue. In New Perspectives in Adipose Tissue: Structure, Function and Development, pp. 45-64 [A Cryer and RLR Van, editors]. London: Butterworths.

Funahashi T, Shimomura I, Hiraoka H, Arai T, Takahashi M, Nakamura T, Nozaki S, Yamashita S, Takemura $\mathrm{K}$, Tokunaga $\mathrm{K}$ \& Matsuzawa Y (1995) Enhanced expression of rat obese $(o b)$ gene in adipose tissues of ventromedial hypothalamus (VMH)lesioned rats. Biochemical and Biophysical Research Communications 211, 469-475.

Garofalo MAR, Kettelhut IC, Roselino JES \& Migliorini RH (1996) Effect of acute cold exposure on norepinephrine turnover rates in rat white adipose tissue. Journal of the Autonomic Nervous System 60, 206-208.

Gettys TW, Harkness PJ \& Watson PM (1996) The $\beta 3$-adrenergic receptor inhibits insulin-stimulated leptin secretion from isolated rat adipocytes. Endocrinology 137, 4054-4057.

Giacobino JP (1996) Role of the $\beta 3$-adrenoceptor in the control of leptin expression. Hormone and Metabolic Research 28, 633-637.
Gong DW, Bi S, Pratley RE \& Weintraub BD (1995) Genomic structure and promoter analysis of the human obese gene. Journal of Biological Chemistry 271, 3971-3974.

Grunfeld C, Zhao C, Fuller J, Pollock A, Moser A, Friedman J \& Feingold KR (1996) Endotoxin and cytokines induce expression of leptin, the $o b$ gene-product, in hamsters - a role for leptin in the anorexia of infection. Journal of Clinical Investigation 97, 2152-2157.

Hales CN, Luzio JP \& Siddle K (1978) Hormonal control of adipose tissue lipolysis. Biochemical Society Symposium 43, 97-135.

Hardie LJ, Guilhot N \& Trayhurn P (1996a) Regulation of leptin production in cultured mature white adipocytes. Hormone and Metabolic Research 28, 685-689.

Hardie LJ, Rayner DV, Holmes S \& Trayhum P (1996b) Circulating leptin levels are modulated by fasting, cold exposure and insulin administration in lean but not Zucker $(\mathrm{fa} / \mathrm{fa})$ rats as measured by ELISA. Biochemical and Biophysical Research Communications 223, 660-665.

Hassink SG, de Lancey E, Sheslow DV, Smith-Kirwin SM, O'Connor DM, Considine RV, Opentanova I, Dostal K, Spear ML, Leef K, Ash M, Spitzer AR \& Funanage VL (1997) Placental leptin: An important new growth factor in intrauterine and neonatal development? Pediatrics 100, E11-E16.

Haynes WG, Morgan DA, Walsh SA, Mark AL \& Sivitz WI (1997) Receptor-mediated regional sympathetic nerve activation by leptin. Journal of Clinical Investigation 100, 270-278.

Hoggard N, Hunter L, Duncan JS, Williams LM, Trayhurn P \& Mercer JG (1997) Leptin and leptin receptor mRNA and protein expression in the murine fetus and placenta. Proceedings of the National Academy of Sciences USA 94, 11073-11078.

Hoggard N, Hunter L, Trayhurn P, Williams LM \& Mercer JG (1998) Leptin and reproduction. Proceedings of the Nutrition Society 57, 421-427.

Hube F, Lietz U, Igel M, Jensen PB, Tornqvist H, Joost HG \& Hauner H (1996) Difference in leptin mRNA levels between omental and subcutaneous abdominal adipose tissue from obese humans. Hormone and Metabolic Research 28, 690-693.

Kallen CB \& Lazar MA (1996) Antidiabetic thiazolidinediones inhibit leptin $(o b)$ gene expression in 3T3-L1 adipocytes. Proceedings of the National Academy of Sciences USA 93, 5793-5796.

Kennedy GC (1953) The role of depot fat in the hypothalamic control of food intake in the rat. Proceedings of the Royal Society of London 140B, 578-592.

Klingenspor M, Dickopp A, Heldmaier G \& Klaus S (1996) Short photoperiod reduces leptin gene expression in white and brown adipose tissue of Djungarian hamsters. FEBS Letters 399, 290-294.

Landsberg L \& Young JB (1984) The role of the sympathoadrenal system in modulating energy expenditure. Clinics in Endocrinology and Metabolism 13, 475-499.

Leroy P, Dessolin S, Villageois P, Moon BM, Friedman JM, Ailhaud G \& Dani C (1996) Expression of $o b$ gene in adipose cells. Regulation by insulin. Journal of Biological Chemistry 271, 2365-2368.

Licinio J, Mantzoros C, Negrao AB, Cizza G, Wong ML, Bongiorno PB, Chrousos GP, Karp B, Allen C, Flier JS \& Gold PW (1997) Human leptin levels are pulsatile and inversely related to pituitary-adrenal function. Nature Medicine 3, 575-579.

Lönnqvist F, Arner P, Nordfors L \& Schalling M (1995a) Overexpression of the obese $(o b)$ gene in adipose tissue of human obese subjects. Nature Medicine 1, 950-953.

Lönnqvist F, Thörne A, Nilsell K, Hoffstedt J \& Arner P (1995b) A pathogenic role of visceral fat $\beta 3$-adrenoceptors in obesity. Journal of Clinical Investigation 95, 1109-1116. 
MacDougald OA, Hwang C-S, Fan H \& Lane MD (1995) Regulated expression of the obese gene product (leptin) in white adipose tissue and 3T3-L1 adipocytes. Proceedings of the National Academy of Sciences USA 92, 9034-9037.

Maffei M, Fei H, Lee G-H, Dani C, Leroy P, Zhang Y, Proenca R, Negrel R, Ailhaud G \& Friedman JM (1995a) Increased expression in adipocytes of $o b$ RNA in mice with lesions of the hypothalamus and with mutations at the $d b$ locus. Proceedings of the National Academy of Sciences USA 92, 6957-6960.

Maffei M, Halaas J, Ravussin E, Pratley RE, Lee GH, Zhang Y, Fei H, Kim S, Lallone R, Ranganathan S, Kern PA \& Friedman JM (1995b) Leptin levels in human and rodent: measurement of plasma leptin and $o b$ mRNA in obese and weight-reduced subjects. Nature Medicine 1, 1155-1161.

Mantzoros CS, Qu DQ, Frederich RC, Susulic VS, Lowell BB, Maratos-Flier E \& Flier JS (1996) Activation of $\beta 3$-adrenergic receptors suppresses leptin expression and mediates a leptinindependent inhibition of food intake in mice. Diabetes $\mathbf{4 5}$, 909-914.

Mantzoros CS, Rosen HN, Greenspan SL, Flier JS \& Moses AC (1997) Short-term hyperthyroidism has no effect on leptin levels in man. Journal of Clinical Endocrinology and Metabolism 82, 497-499.

Masuzaki H, Ogawa Y, Sagawa N, Hosoda K, Matsumoto T, Mise H, Nishimura H, Yoshimasa Y, Tanaka I, Mori T \& Nakao K (1997) Nonadipose tissue production of leptin: Leptin as a novel placenta-derived hormone in humans. Nature Medicine 3, 1029-1033.

Migliorini RH, Garofalo MAR \& Kettelhut IC (1997) Increased sympathetic activity in rat white adipose tissue during prolonged fasting. American Journal of Physiology 41, R656-R661.

Mitchell SE, Rees WD, Hardie LJ, Hoggard N, Tadayyon M, Arch JRS \& Trayhurn P (1997) $o b$ gene expression and secretion of leptin following differentiation of rat preadipocytes to adipocytes in primary culture. Biochemical and Biophysical Research Communications 230, 360-364.

Moinat M, Deng CJ, Muzzin P, Assimacopoulos-Jeannet F, Seydoux J, Dulloo AG \& Giacobino JP (1995) Modulation of obese gene-expression in rat brown and white adipose tissues. FEBS Letters 373, 131-134.

Montague CT, Prins JB, Sanders L, Digby JE \& O'Rahilly S (1997) Depot- and sex-specific differences in human leptin mRNA expression: Implications for the control of regional fat distribution. Diabetes 46, 342-347.

Murakami T, Iida M \& Shima K (1995) Dexamethasone regulates obese expression in isolated rat adipocytes. Bio-chemical and Biophysical Research Communications 214, 1260-1267.

Muzzin P, Revelli JP, Kuhne F, Gocayne JD, Mccombie WR, Venter JC, Giacobino JP \& Fraser CM (1991) An adipose tissuespecific $\beta$-adrenergic receptor - Molecular cloning and downregulation in obesity. Journal of Biological Chemistry 266, 24053-24058.

Ogawa $Y$, Masuzaki H, Isse N, Okazaki T, Mori K, Shigemoto M, Satoh N, Tamura N, Hosoda K, Yoshimasa, Y, Jingami H, Kawada T \& Nakao K (1995) Molecular cloning of rat obese cDNA and augmented gene expression in genetically obese Zucker fatty $(\mathrm{fa} / \mathrm{fa})$ rats. Journal of Clinical Investigation 96, 1647-1652.

Ostlund RE, Yang JW, Klein S \& Gingerich R (1996) Relation between plasma leptin concentration and body fat, gender, diet, age, and metabolic covariates. Journal of Clinical Endocrinology and Metabolism 81, 3909-3913.

Pinkney JH, Coppack SW \& Mohamed-Ali V (1998) Effect of isoprenaline on plasma leptin and lipolysis in humans. Clinical Endocrinology (In the Press).

Rayner DV, Dalgliesh GD, Duncan JS, Hardie LJ, Hoggard N \& Trayhurn P (1997) Postnatal development of the $o b$ gene system: Elevated leptin levels in suckling $f a / f a$ rats. American Journal of Physiology 42, R446-R450.

Rentsch J \& Chiesi M (1996) Regulation of $o b$ gene mRNA levels in cultured adipocytes. FEBS Letters 379, 55-59.

Saladin R, De Vos P, Guerre-Millo M, Leturque A, Girard J, Staels B \& Auwerx J (1995) Transient increase in obese gene expression after food intake or insulin administration. Nature 377, 527-529.

Sinha MK, Sturis J, Ohannesian J, Magosin S, Stephens T, Heiman ML, Polonsky KS \& Caro JF (1996) Ultradian oscillations of leptin secretion in humans. Biochemical and Biophysical Research Communications 228, 733-738.

Slavin BG (1985) The morphology of adipose tissue. In New Perspectives in Adipose Tissue: Structure, Function and Development, pp. 23-43 [A Cryer and RLR Van, editors]. London: Butterworths.

Slieker LJ, Sloop KW, Surface PL, Kriauciunas A, Laquier F, Manetta J, Buevalleskey J \& Stephens TW (1996) Regulation of expression of $o b$ mRNA and protein by glucocorticoids and cAMP. Journal of Biological Chemistry 271, 5301-5304.

Trayhurn $\mathrm{P}$ (1995) Fuel selection in brown adipose-tissue. Proceedings of the Nutrition Society 54, 347-352.

Trayhurn P, Duncan JS \& Rayner DV (1995a) Acute cold-induced suppression of $o b$ (obese) gene expression in white adipose tissue of mice: mediation by the sympathetic system. Biochemical Journal 311, 729-733.

Trayhum P, Duncan JS, Rayner DV \& Hardie LJ (1996) Rapid inhibition of $o b$ gene expression and circulating leptin levels in lean mice by the $\beta 3$-adrenoceptor agonists BRL 35135A and ZD2079. Biochemical and Biophysical Research Communications 228. 605-610.

Trayhurn P, Thomas MEA, Duncan JS \& Rayner DV (1995b) Effects of fasting and refeeding on $o b$ gene expression in white adipose tissue of lean and obese $(o b / o b)$ mice. FEBS Letters 368 , 488-490.

Wabitsch M, Blum WF, Rascher W \& Hauner H (1997) Studies on the regulation of leptin expression using in vitro differentiated human adipocytes. In Leptin - the Voice of Adipose Tissue, pp. 102-109 [WF Blum, W Kiess and W Rascher, editors]. Heidelberg, Germany: J. A. Barth Verlag.

Wabitsch M, Jensen PB, Blum WF, Christoffersen CT, Englaro P, Heinze E, Rascher W, Teller W, Tornqvist H \& Hauner H (1996) Insulin and cortisol promote leptin production in cultured human fat cells. Diabetes 45, 1435-1438.

Yoshida T, Monkawa T, Hayashi M \& Saruta T (1997) Regulation of expression of leptin mRNA and secretion of leptin by thyroid hormone in 3T3-L1 adipocytes. Biochemical and Biophysical Research Communications 232, 822-826.

Youngström TG \& Bartness TJ (1995) Catecholaminergic innervation of white adipose tissue in Siberian hamsters. American Journal of Physiology 37, R744-R751.

Zhang Y, Proenca R, Maffei M, Barone M, Leopold L \& Friedman JM (1994) Positional cloning of the mouse obese gene and its human homologue. Nature 372, 425-432. 